\title{
Impact of semantic or phonemic cues in picture-naming tasks on the calculation of the objective age-of-acquisition norms: A cross-linguistic study
}

\author{
Christine Cannard \\ CNRS, UMR 5105, Université Pierre-Mendès-France, Grenoble, France \\ AND \\ SONIA KandeL \\ CNRS, UMR 5105, Université Pierre-Mendès-France, Grenoble, France \\ and Institut Universitaire de France, Paris, France
}

\begin{abstract}
In picture-naming tasks, participants name a picture as quickly as possible. In several studies, when the participant did not provide the picture name in the first seconds after object presentation, the examiner provided phonemic or semantic cues. Under these conditions, word retrieval should be easier, thus lowering the age of acquisition (AoA). The goal of the present study was to collect objective norms of AoA in French without any kind of cue. The results were then compared with other European databases that relied on picture-naming tasks conducted with phonemic or semantic cues. Globally, the data of all the databases are significantly correlated. However, the AoA measures in these databases are always lower than in our study, except in Álvarez and Cuetos (2007), who did not provide any assistance to the participant. Therefore, giving phonemic and/or semantic cues lowers the AoA values, indicating that the values from different databases in this domain should be taken with caution. The objective AoA norms from this study may be downloaded from the Psychonomic Society's Archive of Norms, Stimuli, and Data, www.psychonomic.org/archive.
\end{abstract}

It is now well established that the age at which a word is acquired, the age of acquisition (AoA), is the best predictor of name agreement in adults (speed and accuracy). The AoA effect is even more important than word frequency in lexical processing (for a review, see Juhasz, 2005). The AoA effect has been evaluated with subjective as well as with objective AoA ratings. The former refers to AoA estimated by adults and the latter concerns children's performance. Most studies used adult estimates to assess the impact of AoA on word processing. This consisted of adults' estimations of when they acquired a word when they were young. Insofar as most adults do not remember the exact age at which they learned a certain word, this calculation method is likely to be influenced by other variables, such as word frequency or familiarity (Barbarotto, Laiacona, \& Capitani, 2005; Cuetos, Aguado, Izura, \& Ellis, 2002). Recently, Sirois, Kremin, and Cohen (2006) also showed the impact on AoA estimation of a participant's age and level of education. The authors indicate that younger participants (18-39 years old) estimated that they learned words earlier than middle-aged (40-59) and older (60-85) participants. Furthermore, the participants with a higher level of education estimated that they learned words earlier than did the ones with a lower level of education. This led some researchers to collect objective AoA data from a picture-naming task performance in several languages: English (Ellis \& Morrison, 1998; Funnell, Hughes, \& Woodcock, 2006; Morrison, Chappell, \& Ellis, 1997), French (Chalard, Bonin, Méot, Boyer, \& Fayol, 2003), Icelandic (Pind, Jónsdóttir, Gossurardóttir, \& Jónsson, 2000), Spanish (Álvarez \& Cuetos, 2007; Pérez \& Navalón, 2005), and Italian (Barbarotto et al., 2005). Although the authors found that objective AoA ratings highly correlated with estimated AoA by adults, the use of objective AoA is recommended, especially because objective ratings are less correlated with other lexical properties than are subjective ones (Álvarez \& Cuetos, 2007; Barbarotto et al., 2005; Bonin, Barry, Méot, \& Chalard, 2004; Chalard et al., 2003; Morrison et al., 1997).

AoA has been extensively investigated with many different types of tasks. Its calculation is therefore crucial in the validation of this concept. Objective AoA was measured using the $75 \%$ rule (Morrison et al., 1997) — that is, the three age bands in which at least $75 \%$ of the children

C. Cannard, christine.cannard@upmf-grenoble.fr 
could name the item correctly. The precise AoA value assigned to a word was the midpoint of the age band, expressed in months. According to Chalard et al. (2003),

For instance, a picture named correctly by at least $75 \%$ of the children in the $78-83$ age band and by at least $75 \%$ of the children in the 84-89 and $90-95$ age bands was assigned an objective AoA value of 80.5 months. Therefore, the word that is used to refer to the picture is considered to be acquired at 80.5 months." (p. 217)

Objective AoA, as we saw, is based on the children's ability to name pictures. A crucial question, according to Zevin and Seidenberg (2002), concerns the problem of predicting performance in lexical tasks with AoA estimations which are also measures of performance. Indeed, in many studies on AoA, there are so many differences in the methodological procedures (see Table 1) that one might question the validity of the children's performance measure in picture naming.

During a picture-naming task, the child names a picture as quickly as possible. In Morrison et al.'s (1997) pioneer study, the children had about $5 \mathrm{sec}$ to give an answer to the question "What is that a drawing of?" If their reply was anything other than the target answer, the experimenter told them to try again and cued them with the initial phoneme of the target response. Pérez and Navalón (2005) and Pind et al. (2000) also offered occasional assistance to the child when the response given by the child was very close to the target word even vaguely. Also, they helped the child if no response was forthcoming within $5 \mathrm{sec}$. Pind et al. gave the syllable attack of the correct word. Pérez and Navalón (2005) gave the semantic category of the object. Barbarotto et al. (2005) encouraged the child to give a generic name. According to these authors, the purpose of cuing is to give the children an opportunity to show their vocabulary and avoid mistakes. We believe that giving cues generates a certain number of problems, especially if the goal of the studies is to collect objective AoA norms.

Retrieving the name of a picture involves multiple stages. According to cascade theoretical models, there are three serially organized stages involved in picture naming: (1) perceptual recognition (i.e., object recognition);
(2) activation of the semantic representation (i.e., semantic activation); and (3) retrieval of the phonological form (i.e., lexical access) (for a review, see Johnson, Paivio, \& Clark, 1996). It is well established that in picture naming, children are less accurate than adults are. Specifically, young children ages 3 to 5 produce more alternative names (the $H$ statistic), ${ }^{1}$ and provide modal names that are often different from the adults' modal names (Berman, Friedman, Hamberger, \& Snodgrass, 1989; Cannard, Blaye, Scheuner, \& Bonthoux, 2005; Cycowicz, Friedman, Rothstein, \& Snodgrass, 1997; D'Amico, Devescovi, \& Bates, 2001; Martein, 1995; Pind et al., 2000; Pompéia, Miranda, \& Bueno, 2001; Wiegel-Crump \& Dennis, 1986). If the experimenter helps the child during the naming task, the child's naming difficulties will be underestimated and the AoA overestimated. The cue can be a distractor, or may interfere in the picture-naming task. The purpose of our study was to provide empirical evidence that giving the initial phoneme or syllable attack of the target facilitates the process of lexical retrieval. The cues bias the access to the lexical-phonological specification, and therefore orient the process toward the correct word.

Jerger, Martin, and Damian (2002) investigated the stages of picture naming with a picture-word task given to children between 5 and 7 years old. During the presentation, each picture appeared with an auditory distractor. The child was instructed to name each picture as quickly and accurately as possible and to ignore the auditory distractor. There were six types of distractors, but only one of them had a congruent onset (i.e., the initial consonant-vowel sequence was congruent with the beginning of the picture name). The results showed that the naming latencies were significantly influenced by the type of onset of the distractor. The congruent onsets significantly facilitated naming performance. These results are in line with Starreveld's (2000) study (cited by Jerger et al., 2002). An auditory input activates a cohort of phonological representations, including the phonologically related picture name. Since the phonological activation converges with the activated representation derived from the picture-naming process, there is a facilitation effect. The retrieval of the phonological forms (i.e., Stage 3 in the cascade model mentioned above) is easier, thus lowering the AoA.

Table 1

Methodological Information on the Different Databases

\begin{tabular}{|c|c|c|c|c|c|}
\hline Study & $\begin{array}{c}\text { Number of } \\
\text { Children } \\
\text { (Age in Years) }\end{array}$ & $\begin{array}{l}\text { Number } \\
\text { of Items }\end{array}$ & Type of Item & Item Source & $\begin{array}{c}\text { Cue in } \\
\text { Picture Naming }\end{array}$ \\
\hline Present study & $960(2 ; 5-9 ; 9)$ & 145 & Black-and-white line drawing & Snodgrass and Vanderwart & No cue \\
\hline Morrison et al. (1997) & $280(2 ; 6-10 ; 11)$ & 297 & Black-and-white line drawing & $\begin{array}{l}\text { Snodgrass and Vanderwart } \\
\text { and other sources }\end{array}$ & Initial phoneme \\
\hline Pind et al. (2000) & $280(2 ; 6-11 ; 0)$ & 238 & Black-and-white line drawing & Snodgrass and Vanderwart & Syllable attack \\
\hline Chalard et al. (2003) & $280(2 ; 6-10 ; 11)$ & 230 & Black-and-white line drawing & Snodgrass and Vanderwart & Initial phoneme \\
\hline Pérez \& Navalón (2005) & $397(2 ; 5-9 ; 0)$ & 178 & Black-and-white line drawing & Pérez and Navalón (2003) & $\begin{array}{l}\text { Semantic category } \\
\text { Initial syllable }\end{array}$ \\
\hline Barbarotto et al. (2005) & $202(2 ; 10-5 ; 9)$ & 80 & Colored photographs & Laiacona et al. (1993) & $\begin{array}{l}\text { If detail, name the } \\
\text { whole item }\end{array}$ \\
\hline Álvarez \& Cuetos (2007) & $380(2 ; 4-15 ; 0)$ & 260 & Black-and-white line drawing & Snodgrass and Vanderwart & No cue \\
\hline
\end{tabular}


We also know that "picture naming should be influenced by both the structural and the semantic relations that may exist between a target and other objects whose representations become activated during target processing" (Humphreys, Riddoch, \& Quinlan, 1988). A picture may generate associated images in multiple modalities (e.g., related objects, sounds, and motor and visceral reactions), referential activation of corresponding names (e.g., object and category names), and subsequent word associations (e.g., names of related objects and properties) (Johnson et al., 1996). Giving the semantic category of the object, as in Pérez and Navalón's (2005) study, minimizes visual complexity. Superordinate information, such as the fruit category for example, distinguishes a peach from a ball. It activates the category members, making it easier for the child to answer. The number of given cues correlated negatively with the age groups; the younger children needed more cues than the older ones did.

In sum, objective AoA refers to naming performance, and giving cues facilitates picture naming. These two facts challenge the reliability of objective AoA measures. According to Morrison et al. (1997), a word and its meaning are acquired when the child can name the picture that represents it. When a majority of the children in an age group can name a picture, "then it is likely that the word is normatively acquired at least as young as that age." If the experimenter provides the initial phoneme or syllable, this will constrain or avoid alternative responses, so the number of correct naming responses will, of course, increase. We determined the number of alternative names for each picture by counting the number of different names the children provided, including the target name. We know that 3and 4-year-old children produced more alternative answers than did the 6- to 8-year-olds, expressed by a higher mean $H$ value: 1.5 and 1.1 for the 3 - and 4 -year-olds, compared with $0.6,0.5$, and 0.4 for the 6-, 7-, and 8-year-olds (Cannard et al., 2005). The occasional assistance offered to the child reduces the objectivity of AoA measures.

Of course, there are other methodological factors that may bias the objectivity of AoA measures. First of all is the children's age, which determines how the age groups are constituted. Another factor that may affect the objectivity of AoA measures is the populations' urban or rural origin. Also, the types of images can increase or lower the children's scores. We focused on cuing; we believe that giving cues constitutes a negative bias, because AoA measures are based on picture-naming performance.

The goal of the present study was to provide a normative database with objective AoA measures that rule out the methodological problems that arise from cuing. We aimed to show that cuing lowers AoA measures, and we compared our data in French with normative data obtained in different linguistic and methodological contexts.

\section{METHOD}

\section{Participants}

A total of 960 French children (age range, 2;9 to 9;9 years) participated in this study. The preschool children's mean age was $4 ; 4$ (range, $2 ; 9-5 ; 10 ; S D=0 ; 9)$. The elementary children's mean age was $7 ; 5$
Table 2

Age Bands

\begin{tabular}{cccc}
\hline $\begin{array}{c}\text { Age Band } \\
\text { (Months) }\end{array}$ & $\begin{array}{c}\text { Mean Age } \\
\text { (Months) }\end{array}$ & $\begin{array}{c}\text { Number of } \\
\text { Females }\end{array}$ & $\begin{array}{c}\text { Number of } \\
\text { Males }\end{array}$ \\
\hline $30-35$ & 34 & 14 & 11 \\
$36-41$ & 38 & 43 & 61 \\
$42-47$ & 44 & 67 & 52 \\
$48-53$ & 51 & 63 & 77 \\
$54-59$ & 56 & 56 & 48 \\
$60-65$ & 62 & 61 & 50 \\
$66-71$ & 68 & 48 & 61 \\
$72-77$ & 75 & 55 & 37 \\
$78-83$ & 80 & 52 & 32 \\
$84-89$ & 86 & 42 & 41 \\
$90-95$ & 92 & 26 & 31 \\
$96-107$ & 101 & 54 & 88 \\
$108-116$ & 112 & 8 & 12 \\
\hline
\end{tabular}

(range, $5 ; 10-9 ; 9 ; S D=0 ; 9$ ). As in Chalard et al. (2003), the age groups were formed in 6-month intervals, from 2 years 9 months to 7 years 11 months, then in 12-month intervals, from 8 years to 9 years 9 months, to achieve a more exact AoA measure. Table 2 presents information about the children in each of the age bands.

All the children came from schools in the Grenoble region, from rural locations of less than 5,000 inhabitants, to medium-sized locations of between 20,000 and 50,000 inhabitants, to the urban environment of Grenoble with 155,000 inhabitants. The children belonged to middle-class and upper-middle-class families. They were native French speakers. All the schools that participated in the study were public schools. Informed consent was obtained from schools and parents before the study was carried out.

\section{Material}

At the onset, we collected information on naming performance of a large sample of children on 360 images (see database at web .upmf-grenoble.fr/Banque_images/). We did so because several researchers in our laboratory required this information for running their own experiments. However, since Snodgrass and Vanderwart's (1980) pictures are most widely used in the literature, for the present study we focused our analysis only on the 145 items in common. The set of 145 pictures was extracted from Cannard et al. (2005). The pictures were black outline drawings on a white background. Each picture occupied a square of $6 \times 6 \mathrm{~cm}$ on an A4-format sheet of paper. The selected pictures were divided into two lists. The sets were presented randomly to each participant, either from list 1 or list 2 . Two groups of 80 children at each age were tested, resulting in a total of $2 * 80 * 6=960$ children. The entries are listed according to the identifying numbers originally assigned to each drawing by Snodgrass and Vanderwart and Cycowicz et al. (1997).

\section{Procedure}

The procedure during the picture-naming task was the same as that used by Cycowicz et al. (1997). Each child was tested individually on a single list of pictures in a quiet room at school, during a 15to 20-min session. The child was instructed to look carefully at the black-and-white line-drawn object and to answer the question "What is this picture?" When the child did not recognize the object depicted, or did not say anything, we presented the next picture. When the child could not name the picture, we tried to determine whether he or she knew the concept and asked "What can you do with it?" or "Where have you seen it?" There was no feedback or cue. Incorrect answers were left uncorrected. We encouraged the children regularly throughout each test session. For the younger children, we asked them every $10 \mathrm{~min}$ whether they were tired.

\footnotetext{
Measures

Name agreement values. Picture-naming values were extracted from Cannard et al.'s (2005) database that provides French children's
} 
picture-naming norms for name agreement. The authors noted all the alternative answers, but they only accepted the exact name as a correct answer. They even excluded the answers that indicated that the children knew the concept (e.g., "Mom uses it to cook with"). Indeed, the authors showed that the usual measures of name agreement based on modal names were always higher than was the measure of name agreement expressed by the percentage of participants naming the picture with its expected name, especially very young children. Thus, the assessment of objective AoA in the present study is calculated on name agreement based on the production percentage of the expected name.

AoA values. Objective AoA was measured using Morrison et al.'s (1997) $75 \%$ rule. In the present article, adults' name agreement scores were taken from Alario and Ferrand (1999), who provide French normative measures for 260 of Snodgrass and Vanderwart's (1980) pictures. As did Chalard et al. (2003), we based our AoA measures on the following rules:

1. No AoA value was assigned to the items in which name agreement in adults was below $75 \%$.

2 . The $75 \%$ rule was strictly applied even for some items that easily reached the $75 \%$ criterion in the youngest age band (sometimes $100 \%$ ), although it is possible that they would be acquired earlier.

3. When name agreement in both adults and children in the two last age bands was at least $75 \%$ or above, the items were assigned to the last but one age band.

4. When name agreement in both adults and children in the oldest age band was at least $75 \%$, the items were assigned an AoA score of 140.5. To allow easy reference with Chalard et al. (2003), we noted this same arbitrary value, which corresponds for them to the midpoint of the 11;6-11;11 age band, the second 6-month interval above the oldest age band. It was chosen in order to avoid excessively "optimistic" objective AoA values that might occur as a consequence of sampling variability, and to take into account the fact that the words belonged to the adults' vocabulary (Chalard et al., 2003, p. 218).

5 . When the items did not achieve the percentage criterion in the older age band, they were not assigned objective AoA scores (outliers).

\section{RESULTS AND DISCUSSION}

The Appendix presents, for each picture, the following information: (1) the item number (cf. Cycowicz et al.'s [1997] norms); (2) the expected name in French; (3) its English translation. The next six columns of the Appendix present objective AoA scores according to the $75 \%$ rule in the present study (column 4), Chalard et al. (2003) (column 5), Pind et al. (2000) (column 6), Morrison et al. (1997) (column 7), Barbarotto et al. (2005) (column 8), Pérez and Navalón (2005) (column 9), and Álvarez and Cuetos (2007) (column 10).

\section{Objective AoA Norms in French Without Phonemic or Semantic Cue During Picture Naming}

When the set of the $75 \%$ rule was applied:

1. Seven items could not be assigned an objective AoA value (as indicated by a dash in the Appendix), because the name agreement in the older age band and in adults was below 75\%: wrench (clé), stove (cuisinière), clock (horloge), lips (lèvres), toe (orteil), peach (pêche), and pitcher (pot-à-eau).

2. In order to keep more common items with the other databases, five items were considered as acquired and were assigned the AoA values which correspond to the $75 \%$ rule, although the percentage of correct naming in adults was below $75 \%$ (as indicated in bold in the Appendix): train (train), pen (stylo), refrigerator (réfrigérateur), leaf (feuille), and sailboat (voilier).

3 . Twenty-three items reached the $75 \%$ criterion in the youngest age band (i.e., name agreement in at least $90 \%$ of children, indicated by an asterisk in the Appendix): airplane (avion), ball (ballon), banana (banane), truck (camion), duck (canard), chair (chaise), hat (chapeau), dog (chien), scissors (ciseaux), knife (couteau), spoon (cuillère), flower (fleur), rabbit (lapin), bed (lit), glasses (lunettes), hand (main), house (maison), bird (oiseau), basket ( panier), trousers ( pantalon), butterfly (papillon), foot (pied), and telephone (téléphone).

4. Twelve items did not achieve the percentage criterion in the oldest age band (outliers, indicated by a "+" in the Appendix): bee (abeille), hair (cheveux), hanger (cintre), dresser (commode), rooster (coq), light switch (interrupteur), skirt (jupe), mitten (moufle), cloud (nuage), pliers (pince), bowl (saladier), and screw (vis).

It is noteworthy that the items excluded by application of Morrison et al.'s (1997) 75\% rule were quite ambiguous in the black-and-white drawings. For instance, it was difficult to distinguish a rooster from a chicken (item 191), or to identify the cloud (item 62) or hair (item 113), because the picture is not easy to recognize out of context. These items generated many alternative answers (cf. $H$ indexes in Cannard et al., 2005), even in the last age group (8-year-olds). Consequently, these items did not meet the $75 \%$ criterion, although the names of the pictures are very common in the children's vocabulary. AoA measures refer to the child's ability to name an object in a picture-naming task, but sometimes it is difficult to identify and visually distinguish the image. This is why the material may have an impact on AoA calculations.

When the remaining 126 items that were not assigned AoA values were removed, the average objective AoA in this experiment was 4.5 years (54.67 months).

\section{Comparison With Other Normative Databases}

Since the size of the samples varied from one study to another, we compared only the data referring to the items in common. This was done after the application of the $75 \%$ rule. The items with,-+ , or blank spaces were therefore excluded from the statistical analyses. Then we compared our objective AoA scores with the objective AoA scores of six databases for the remaining items.

Table 3 presents (1) the number of items in common between our study and another one; (2) the average objective AoA in each study for the remaining items; (3) AoA range; (4) the average objective AoA in our study for the remaining items; (5) the $t$ tests, and (6) the correlations between the present study's objective AoA scores and objective AoA scores in six other studies.

In all these studies, except for Álvarez and Cuetos's (2007), the experimenter provided cues whenever the child gave an answer that was either close to or distant from the target word, or if the child did not produce a response within $5 \mathrm{sec}$. Morrison et al. (1997) and Chalard et al. (2003) provided the initial phoneme of the target name. Pind et al. (2000) provided information on the syl- 
Table 3

Mean Age-of-Acquisition Values and Statistical Comparisons Among Databases

\begin{tabular}{|c|c|c|c|c|c|c|c|c|c|}
\hline \multirow[b]{2}{*}{ Study } & \multirow{2}{*}{$\begin{array}{c}\text { Number of } \\
\text { Remaining Items } \\
\text { in Common }\end{array}$} & \multicolumn{2}{|c|}{$\begin{array}{c}\text { AoA for } \\
\text { Remaining Items } \\
\text { in Common } \\
\end{array}$} & \multicolumn{2}{|c|}{$\begin{array}{c}\text { Mean } \\
\text { AoA Range } \\
\end{array}$} & \multicolumn{2}{|c|}{$\begin{array}{c}\text { AoA in } \\
\text { Our Study for } \\
\text { Remaining Items } \\
\text { in Common } \\
\end{array}$} & \multirow[b]{2}{*}{$t$} & \multirow{2}{*}{$\begin{array}{c}\text { Correlation } \\
\text { Between Data }\end{array}$} \\
\hline & & $M$ & $S D$ & Min & Max & $M$ & $S D$ & & \\
\hline Morrison et al. (1997) & 110 & 38.33 & 16.95 & 22.1 & 102.5 & 53.66 & 22.84 & $5.66^{* * *}$ & $.58^{* *}$ \\
\hline Pind et al. (2000) & 115 & 41.41 & 19.74 & 22.5 & 140 & 54.35 & 22.87 & $4.60^{* * *}$ & $.53^{* *}$ \\
\hline Chalard et al. (2003) & 116 & 49.47 & 17.21 & 30.6 & 113.5 & 52.80 & 21.24 & $1.312^{\dagger}$ & $.82^{* *}$ \\
\hline Pérez and Navalón (2005) & 66 & 41.32 & 13.77 & 32 & 91 & 53.51 & 23.21 & $3.67^{* * *}$ & $.67^{* *}$ \\
\hline Barbarotto et al. (2005) & 30 & 45.95 & 10.46 & 34 & 66.5 & 50.97 & 18.57 & $1.29^{\dagger}$ & $.65^{* *}$ \\
\hline Álvarez and Cuetos (2007) & 120 & 56.57 & 31.88 & 30 & 185 & 54.67 & 24.03 & $-0.52^{\dagger}$ & $.61^{* *}$ \\
\hline
\end{tabular}

${ }^{* *} p<.01 . \quad{ }^{* * *} p<.001 . \quad \dagger$ in.s.

lable attack of the target name. In Pérez and Navalón's (2005) Spanish research, the experimenters provided cues on the semantic category of the item and the first syllable of the target name (semantic and phonological cues). Finally, in Barbarotto et al. (2005), if the child named only a detail of the picture, the examiner asked the child to name the whole item. As we can see from this table, the correlations between our values of objective AoA and the values obtained in other investigations are significant in all cases. The correlation between our data and Chalard et al.'s is particularly high (.82), because in both studies the populations are French children. The correlations are also high with Barbarotto et al. and Álvarez and Cuetos, .65 and .61 , respectively. In the latter, the authors did not provide the first phoneme, as has been done in other studies. Despite the limited number of stimuli in common (66) and a very significant difference between mean AoAs $[t(130)=$ $0.67, p<.001]$, the pattern of our results is rather similar to Pérez and Navalón's $(2005)(0.67, p<.01)$.

Table 3 also reveals that the objective AoA means decrease when the experimenter provides any kind of cues. Despite the significant correlations, it seems rather clear that the cues do have an impact on the naming scores and therefore on AoA. There are several items in all studies where the differences are notable (see the Appendix). In Pind et al. (2000), items 149 (mouse) and 224 (sweat) were assigned an AoA value of 23 months, which contrasts with our AoA values of 75 and 68 months, respectively. Item 171 (piano) had an AoA value of 140 months in Pind et al.'s study, against an AoA of 63 months in ours. Many items, like mouse, nail, nose, ear, drum, and leg, were acquired earlier by the Spanish children in Pérez and Navalón's (2005) study than they were by the French children. Bee, skirt, mitten, and rooster could not be assigned an AoA value in our study, whereas in Chalard et al.'s (2003) norms the AoA value was 75 months. The picture of the mouse (item 149) had an AoA of 75 months in our research, which contrasts with an AoA of 32.5 months in Chalard et al.'s norms. The same remarks apply for the data presented by Morrison et al. (1997).

A high $H$ reflects a low dispersion name, and therefore a low percentage of expected correct responses. In children, the above-mentioned items had higher $H$ scores than 1.5 (Cannard et al., 2005). The drawing of a nail, for instance, yields many alternative responses in young children $(H=$
2.69 at 3 years old $)$, as does the drawing of the drum $(H=$ 1.93). Name dispersion affects the calculation of the AoA mean, since the precise AoA value assigned to a word was the midpoint of the age band expressed in months in the first three age bands, in which at least $75 \%$ of the children could name the item correctly. For example, mouse (item 149), which was named correctly by at least $75 \%$ of the children in the $66-71$ age band and by at least $75 \%$ of the children in the 72-77 and 78-83 age bands, was assigned an objective AoA value of 68 months. Therefore, the word that refers to the picture is considered to be acquired at 68 months in our study, versus 33 months in Chalard et al. (2003), 23 months in Morrison et al. (1997) and Pind et al. (2000), and 45 months in Pérez and Navalón (2005). As mentioned by the latter, facilitating the semantic category of the item or giving the first syllable of the name-when the child did not recognize a picture because the picture was not easy to identify, or when the child used a word to refer to a semantically similar concept (e.g., cat for the picture of the lion) - would help the subject to select an answer and orientate the response toward the target word (p. 187). In Pérez and Navalón's (2005) study, the percentage of correct responses with phonologic cues was $18 \%$ of the total of correct responses. This might appear low; however, we consider that the authors (1) selected from Pérez and Navalón's (2003) database pictures that are visually more adequate for young children than are Snodgrass and Vanderwart's (1980) ones; and (2) selected only items with a low name dispersion (i.e., $H$ scores near 0 ), reducing the variability of $H$. This may explain why the AoA was much lower. Regarding Barbarotto et al.'s (2005) study, it is difficult to compare the data, because they used 80 color photographs. Moreover, we do not know the values above 69 months, and only 30 words with AoA values are common to the two studies. Finally, we would like to point out that the recent data presented by Álvarez and Cuetos (2007) reinforces our results. It is the only study that did not provide any phonological assistance during the picture-naming task. Although their population was Spanish and ours is French, the mean AoAs are similar. When the items without AoA values were removed, there were 120 words in common. The average of our study was 54.67 months and Álvarez and Cuetos's was 56.57 months. This supports the idea that phonological cues have an impact on AoA calculation. 
In sum, AoA is a crucial variable for psycholinguists and clinicians. It is therefore important to associate objective AoA measures to the images used in picture-naming tasks. As mentioned above, there are three serially organized stages involved in picture naming: (1) perceptual recognition; (2) activation of the semantic representation; and (3) retrieval of the phonological form (see Johnson et al., 1996, for a review). The children can make "mistakes" at any of the three stages that lead to naming an image. AoA studies do not aim to improve the child's performance; their goal is to know at which age a given word is objectively acquired. If the experimenter helps the child by giving cues, there is facilitation in the three stages. The cues therefore bias the children's answer, because they interfere in the naming process. In addition, not all the children receive cues and not all the pictures require giving cues. Finally, the cues that have been given by the studies mentioned above are different. Giving cues is thus not systematic; it is extremely variable. This variability might have a negative impact on the objective AoA values.

\section{CONCLUSION}

Picture naming is a widely used technique in psycholinguistic and cognitive research. In their review of the picture-naming literature, Johnson et al. (1996) revealed how different naming stages are influenced by item attributes, task conditions, and participant characteristics. The influence of AoA in lexical processing, although it seems a never ending story (Bonin et al., 2004), is now widely established (review in Juhasz, 2005). However, there is an aspect of AoA measures that requires attention: The procedure that leads to the name agreement values on which AoA norms are based. Indeed, in the majority of studies, the experimenter offers occasional assistance to the child, facilitating linguistic production. The purpose of the present study was to provide new objective AoA norms from picture naming in French without any semantic or phonemic cues. We compared these AoA values to norms of databases in other languages. The results revealed that our AoA measures were always higher than in the studies that provided cues. Furthermore, they are in agreement with Álvarez and Cuetos (2007), who did not provide any cues either. This multicultural comparison suggests an equivalent order of acquisition of the words in different languages, but raised the question of the effects of picturenaming task conditions on AoA measures.

Finally, we would like to point out that if "giving cues" had been manipulated within participants, our results would have been stronger. However, the notable discrepancies between the norms of the studies that provided cues (Chalard et al., 2003; Morrison et al., 1997; Pérez \& Navalón, 2005; Pind et al., 2000) and those that did not (i.e., Álvarez \& Cuetos, 2007; Barbarotto et al., 2005) strongly suggest that research involving pictorial processing should be cautious when using norms from databases with different procedures. In particular, giving cues during picture naming improves performance, especially when the items generate many alternative answers, and therefore biases the reliance of the objective AoA norms.

\section{AUTHOR NOTE}

This article was supported by a grant from the French Ministry of Research (ACI Cognitique 2000). The pictures used in this study belong to our normative database and are available online (www.upmf-grenoble .fr/Banque_images/). The picture-naming norms may be downloaded from www.psychonomic.org/archive. The authors thank local school inspectors, teachers, parents, and children for their cooperation, and those colleagues who made very helpful comments on a previous version of the manuscript. We also thank Frederic Entenmann for linguistic support. Correspondence concerning this article should be addressed to C. Cannard, Laboratoire de Psychologie et NeuroCognition, CNRS UMR 5105, Université Pierre-Mendés-France, Bâtiment des Sciences de l'Homme et des Mathématiques, BP 47, 38040 Grenoble, France (e-mail: christine.cannard@upmf-grenoble.fr).

\section{REFERENCES}

Alario, F. X., \& Ferrand, L. (1999). A set of 400 pictures standardized for French: Norms for name agreement, image agreement, familiarity, visual complexity, image variability, and age of acquisition. Behavior Research Methods, Instruments, \& Computers, 31 531-552.

Álvarez, B., \& Cuetos, F. (2007). Objective age of acquisition norms for a set of 328 words in Spanish. Behavior Research Methods, 39, 377-383.

Barbarotto, R., Laiacona, M., \& Capitani, E. (2005). Objective versus estimated age of word acquisition: A study of 202 Italian children. Behavior Research Methods, 37, 644-650.

Berman, S., Friedman, D., Hamberger, M., \& Snodgrass, J. G. (1989). Developmental picture norms: Relationships between name agreement, familiarity, and visual complexity for child and adult ratings of two sets of line drawings. Behavior Research Methods, Instruments, \& Computers, 21, 371-382.

Bonin, P., Barry, C., MÉot, A., \& Chalard, M. (2004). The influence of age of acquisition in word reading and other tasks: A never ending story? Journal of Memory \& Language, 50, 456-476.

Cannard, C., Blaye, A., Scheuner, N., \& Bonthoux, F. (2005). Picture naming in 3- to 8-year-old French children: Methodological considerations for name agreement. Behavior Research Methods, 37, 417-425.

Chalard, M., Bonin, P., Méot, A., Boyer, B., \& Fayol, M. (2003). Objective age-of-acquisition (AoA) norms for a set of 230 object names in French: Relationships with psycholinguistic variables, the English data from Morrison et al. (1997), and naming latencies. European Journal of Cognitive Psychology, 15, 209-245.

Cuetos, F., Aguado, G., Izura, C., \& Ellis, A. W. (2002). Aphasic naming in Spanish: Predictors and errors. Brain \& Language, 82, 344-365.

Cycowicz, Y. M., Friedman, D., Rothstein, M., \& Snodgrass, J. G. (1997). Picture naming by young children: Norms for name agreement, familiarity, and visual complexity. Journal of Experimental Child Psychology, 65, 171-237.

D’Amico, S., Devescovi, A., \& Bates, E. (2001). Picture naming and lexical access in Italian children and adults. Journal of Cognition \& Development, 2, 71-105.

Ellis, A. W., \& Morrison, C. M. (1998). Real age-of-acquisition effects in lexical retrieval. Journal of Experimental Psychology: Learning, Memory, \& Cognition, 24, 515-523.

Funnell, E., Hughes, D., \& Woodcock, J. (2006). Age of acquisition for naming and knowing: A new hypothesis. Quarterly Journal of Experimental Psychology, 59, 268-295.

Humphreys, G. W., Riddoch, M. J., \& Quinlan, P. T. (1988). Cascade processes in picture identification. Cognitive Neuropsychology, 5, 67-104.

Jerger, S., Martin, R. C., \& Damian, M. F. (2002). Semantic and phonological influences on picture naming by children and teenagers. Journal of Memory \& Language, 47, 229-249.

Johnson, C. J., Paivio, A., \& Clark, J. M. (1996). Cognitive components of picture naming. Psychological Bulletin, 120, 113-139.

JuHAsz, B. J. (2005). Age-of-acquisition effects in word and picture identification. Psychological Bulletin, 131, 684-712.

Martein, R. (1995). Norms for name and concept agreement, familiar- 
ity, visual complexity and image agreement on a set of 216 pictures. Psychologica Belgica, 35, 205-225.

Morrison, C. M., Chappell, T. D., \& Ellis, A. W. (1997). Age of acquisition norms for a large set of object names and their relation to adult estimates and other variables. Quarterly Journal of Experimental Psychology, 50A, 528-559.

PÉreZ, M.-Á., \& NAVALóN, C. (2003). Normas españolas de 290 nuevos dibujos: Acuerdo en la denominación, concordancia de la imagen, familiaridad, complejidad visual y variabilidad de la imagen. Psicológica, 24, 215-241.

Pérez, M.-Á., \& Navalón, C. (2005). Objective-AoA norms for 175 names in Spanish: Relationships with other psycholinguistic variables, estimated AoA, and data from other languages. European Journal of Cognitive Psychology, 17, 179-206.

Pind, J., JónsdótTir, H., Gossurardóttir, H., \& Jónsson, F. (2000). Icelandic norms for the Snodgrass and Vanderwart (1980) pictures: Name and image agreement, familiarity, and age of acquisition. Scandinavian Journal of Psychology, 41, 41-48.

Pompéia, S., Miranda, M., \& Bueno, O. (2001). A set of 400 pictures standardised for Portuguese: Norms for name agreement, familiarity and visual complexity for children and adults. Arquivos de NeuroPsiquiatria, 59, 330-337.

Sirois, M., Kremin, H., \& Cohen, H. (2006). Picture-naming norms for Canadian French: Name agreement, familiarity, visual complexity, and age of acquisition. Behavior Research Methods, 38, 300-306.

SNODGRASS, J. G., \& VANDERWART, M. (1980). A standardized set of 260 pictures: Norms for name agreement, image agreement, familiarity, and visual complexity. Journal of Experimental Psychology: Human Learning \& Memory, 6, 174-215.

Starreveld, P. A. (2000). On the interpretation of onsets of auditory context effects in word production. Journal of Memory \& Language, 42, 497-525.
Wiegel-Crump, C. A., \& Dennis, M. (1986). Development of wordfinding. Brain \& Language, 27, 1-23.

Zevin, J. D., \& Seidenberg, M. S. (2002). Age of acquisition effects in word reading and other tasks. Journal of Memory \& Language, 47, 1-29.

\section{NOTE}

1. The $H$ statistic is a logarithmic function that analyzes the quantity of different names that an object receives. It is computed for each picture with the formula $\Sigma_{i}^{k}=P_{i} \log _{2}\left(1 / P_{i}\right)$, where $k$ refers to the number of different names given to each picture and $P_{i}$ is the proportion of participants who gave each name. An $H$ near 0 indicates a low dispersion, and therefore a high name agreement (Snodgrass \& Vanderwart, 1980).

\section{ARCHIVED MATERIALS}

The following materials may be accessed through the Psychonomic Society's Norms, Stimuli, and Data archive, www.psychonomic.org/ archive.

To access these files, search the archive for this article using the journal (Behavior Research Methods), the first author's name (Cannard), and the publication year (2008).

FILE: Cannard-BRM-2008.zip

DESCRIPTION: The compressed archive file contains two files:

appendix2008.pdf, containing the objective French AoA norms in .pdf format.

appendix2008.xls, containing the above information in Excel spreadsheet format.

AUTHOR's E-MAIL ADDRESS: chirstine.cannard@upmf-grenoble.fr. 
APPENDIX

Objective Age-of-Acquisition Norms in French and Other European Languages

\begin{tabular}{|c|c|c|c|c|c|c|c|c|c|}
\hline $\begin{array}{l}\text { Item } \\
\text { No. }\end{array}$ & French Name & English Name & $\begin{array}{c}\text { Present } \\
\text { Study }\end{array}$ & $\begin{array}{c}\text { Chalard } \\
\text { et al. } \\
(2003)\end{array}$ & $\begin{array}{l}\text { Pind } \\
\text { et al. } \\
(2000)\end{array}$ & $\begin{array}{c}\text { Morrison } \\
\text { et al. } \\
\text { (1997) }\end{array}$ & $\begin{array}{c}\text { Barbarotto } \\
\text { et al. } \\
(2005)\end{array}$ & $\begin{array}{c}\text { Pérez \& } \\
\text { Navalón } \\
(2005)\end{array}$ & $\begin{array}{c}\text { Álvarez \& } \\
\text { Cuetos } \\
(2007)\end{array}$ \\
\hline 1 & accordéon & accordion & 80 & 75 & 81 & & & & 136 \\
\hline 2 & avion & airplane & $34^{*}$ & 33 & 23 & 23 & 37 & 32 & 30 \\
\hline 5 & fourmi & ant & 75 & 69 & 87 & 63 & & 52 & 102 \\
\hline 7 & bras & arm & 75 & 63 & 33 & 39 & 61 & & 82 \\
\hline 12 & hache & axe & 101 & 75 & 63 & 63 & & 91 & 76 \\
\hline 14 & ballon & ball & $34^{*}$ & 33 & 23 & 23 & & 32 & 36 \\
\hline 16 & banane & banana & $34^{*}$ & 39 & 23 & 23 & 34 & 32 & 30 \\
\hline 20 & panier & basket & $34^{*}$ & 39 & 39 & 39 & & & 43 \\
\hline 21 & ours & bear & 63 & 51 & 39 & 51 & & 40 & 61 \\
\hline 22 & lit & bed & $34^{*}$ & 33 & 33 & 22 & 34 & 45 & 36 \\
\hline 23 & abeille & bee & + & 75 & - & 57 & & & 173 \\
\hline 27 & vélo & bicycle & 34 & 33 & 33 & & 34 & 45 & 30 \\
\hline 28 & oiseau & bird & $34^{*}$ & 33 & 23 & & & & 49 \\
\hline 30 & livre & book & 39 & 33 & 33 & 22 & & 32 & 36 \\
\hline 31 & botte & boot & 34 & 33 & - & 23 & & & 54 \\
\hline 32 & bouteille & bottle & 34 & 33 & 39 & 39 & & & 36 \\
\hline 34 & saladier & bowl & + & 69 & 39 & 57 & & & 173 \\
\hline 37 & balai & broom & 44 & 45 & - & 87 & & & 36 \\
\hline 38 & brosse à cheveux & brush & 75 & 75 & 51 & 23 & & & 93 \\
\hline 40 & papillon & butterfly & $34^{*}$ & 33 & 33 & 23 & 34 & 40 & 36 \\
\hline 41 & bouton & button & 56 & 69 & 57 & 39 & & & 36 \\
\hline 42 & gâteau & cake & 80 & 75 & 39 & 23 & & & \\
\hline 47 & voiture & car & 34 & 33 & 23 & 22 & 34 & 32 & 30 \\
\hline 48 & carotte & carrot & 34 & 39 & 33 & 25 & & & 43 \\
\hline 50 & chenille & caterpillar & 63 & 69 & - & 45 & & & 185 \\
\hline 53 & chaise & chair & $34^{*}$ & 33 & 23 & 22 & 34 & 32 & 36 \\
\hline 60 & réveil & clock & - & 81 & 23 & 22 & & & 30 \\
\hline 61 & pince à linge & clothespin & 80 & 93 & 39 & & & & 49 \\
\hline 62 & nuage & cloud & + & - & 75 & 57 & & & 102 \\
\hline 65 & peigne & comb & 68 & 57 & 33 & 39 & & 32 & 36 \\
\hline 67 & canapé & couch & 80 & 45 & 28 & & & & 102 \\
\hline 68 & vache & cow & 51 & 51 & 51 & 23 & 43 & 32 & 36 \\
\hline 70 & tasse & cup & 101 & 75 & 39 & 25 & & 40 & 66 \\
\hline 73 & chien & $\operatorname{dog}$ & $34^{*}$ & 33 & 33 & 22 & & 32 & 36 \\
\hline 75 & âne & donkey & 63 & 57 & 69 & 51 & & 52 & 61 \\
\hline 76 & porte & door & 39 & 33 & 33 & 22 & & 32 & 30 \\
\hline 78 & robe & dress & 68 & 51 & 28 & 39 & & & 43 \\
\hline 79 & commode & dresser & + & - & 75 & & & & 185 \\
\hline 80 & tambour & drum & 68 & 75 & 39 & 51 & 43 & 32 & 43 \\
\hline 81 & canard & duck & $34^{*}$ & 39 & 51 & 22 & & 45 & 36 \\
\hline 83 & oreille & ear & 63 & 51 & 45 & 45 & 61 & 40 & 102 \\
\hline 84 & éléphant & elephant & 34 & 33 & 23 & 23 & & 32 & 30 \\
\hline 86 & œil & eye & 39 & 57 & 33 & 45 & & 40 & 30 \\
\hline 88 & doigt & finger & 39 & 39 & 69 & 23 & & 32 & 36 \\
\hline 89 & poisson & fish & 34 & 33 & 23 & 22 & & & 36 \\
\hline 91 & fleur & flower & $34^{*}$ & 33 & 23 & 22 & & & 36 \\
\hline 93 & mouche & fly & 92 & 75 & 51 & 57 & & 32 & 136 \\
\hline 94 & pied & foot & $34^{*}$ & 33 & 33 & 39 & & & 36 \\
\hline 97 & fourchette & fork & 34 & 33 & 33 & 23 & & 32 & 30 \\
\hline 100 & grenouille & frog & 39 & 39 & 33 & 23 & & & 136 \\
\hline 103 & girafe & giraffe & 34 & 33 & 33 & 39 & 43 & 32 & 49 \\
\hline 105 & lunettes & glasses & $34^{*}$ & 33 & 28 & 23 & & 52 & 30 \\
\hline 106 & gant & glove & 68 & 51 & 51 & 45 & & 32 & 61 \\
\hline 109 & raisin & grapes & 51 & 57 & 57 & 57 & 49 & & 43 \\
\hline 111 & guitare & guitar & 39 & 51 & 39 & 63 & & 40 & 49 \\
\hline 113 & cheveux & hair & + & - & 51 & 57 & & & \\
\hline 114 & marteau & hammer & 56 & 57 & 39 & 25 & 49 & & 36 \\
\hline 115 & main & hand & $34^{*}$ & 33 & 39 & 23 & 34 & & 36 \\
\hline 116 & cintre & hanger & + & 141 & 75 & & & & 61 \\
\hline
\end{tabular}




\begin{tabular}{|c|c|c|c|c|c|c|c|c|c|}
\hline \multicolumn{10}{|c|}{ APPENDIX (Continued) } \\
\hline $\begin{array}{l}\text { Item } \\
\text { No. }\end{array}$ & French Name & English Name & $\begin{array}{l}\text { Present } \\
\text { Study }\end{array}$ & $\begin{array}{c}\text { Chalard } \\
\text { et al. } \\
(2003)\end{array}$ & $\begin{array}{l}\text { Pind } \\
\text { et al. } \\
(2000) \\
\end{array}$ & $\begin{array}{c}\text { Morrison } \\
\text { et al. } \\
(1997)\end{array}$ & $\begin{array}{c}\text { Barbarotto } \\
\text { et al. } \\
(2005)\end{array}$ & $\begin{array}{c}\text { Pérez \& } \\
\text { Navalón } \\
(2005)\end{array}$ & $\begin{array}{c}\text { Álvarez \& } \\
\text { Cuetos } \\
(2007)\end{array}$ \\
\hline 118 & chapeau & hat & $34^{*}$ & 33 & 33 & 23 & & 40 & 61 \\
\hline 120 & hélicoptère & helicopter & 51 & 51 & 33 & 23 & 49 & 40 & 61 \\
\hline 55 & poule & hen & 63 & 51 & non & 51 & & 32 & \\
\hline 121 & cheval & horse & 39 & 33 & 23 & 23 & & 32 & 30 \\
\hline 122 & maison & house & $34^{*}$ & 33 & 23 & 22 & & 32 & 30 \\
\hline 123 & fer à repasser & iron & 80 & non & 51 & 45 & & & 61 \\
\hline 124 & table à repasser & ironing board & 140.5 & non & - & & & & 102 \\
\hline 126 & kangourou & kangaroo & 56 & 57 & 39 & 45 & & & 72 \\
\hline 128 & clé voiture & key & 34 & 45 & 23 & 23 & & & 36 \\
\hline 129 & cerf-volant & kite & 63 & non & 51 & 39 & & & 49 \\
\hline 130 & couteau & knife & $34^{*}$ & 33 & 28 & 23 & & & 36 \\
\hline 131 & échelle & ladder & 51 & 51 & 39 & 25 & & 40 & 36 \\
\hline 132 & lampe & lamp & 63 & 51 & 39 & 75 & 67 & & 61 \\
\hline 133 & feuille & leaf & 39 & 39 & 45 & 25 & & & 49 \\
\hline 134 & jambe & leg & 68 & 75 & 33 & 39 & 49 & 32 & 72 \\
\hline 138 & ampoule & light bulb & 101 & 69 & 51 & 103 & & & 66 \\
\hline 139 & interrupteur & light switch & + & 141 & - & & & & 150 \\
\hline 140 & lion & lion & 34 & 51 & 23 & 23 & & 40 & 36 \\
\hline 141 & lèvres & lips & - & 75 & 57 & 51 & 61 & 40 & \\
\hline 144 & moufle & mitten & + & 75 & 28 & 115 & & & 160 \\
\hline 145 & singe & monkey & 39 & 45 & 23 & 25 & & 32 & 43 \\
\hline 147 & moto & motorcycle & 34 & 33 & 39 & 39 & 34 & 32 & 49 \\
\hline 149 & souris & mouse & 75 & 33 & 23 & 23 & 43 & 45 & 36 \\
\hline 150 & champignon & mushroom & 44 & 39 & 39 & 63 & 49 & 52 & 54 \\
\hline 151 & clou & nail & 101 & 75 & 57 & 69 & & 52 & 82 \\
\hline 153 & collier & necklace & 44 & 45 & - & 51 & & & 43 \\
\hline 155 & nez & nose & 75 & 75 & 45 & 57 & & 32 & 61 \\
\hline 158 & orange & orange & 92 & 69 & 33 & 39 & 49 & 57 & 61 \\
\hline 161 & pinceau & paintbrush & 51 & 51 & 39 & 51 & & & 61 \\
\hline 179 & casserole & pan & 44 & 57 & non & 45 & & & \\
\hline 163 & pêche & peach & - & - & - & 103 & & & \\
\hline 166 & poire & pear & 44 & 57 & 33 & 45 & & 32 & 43 \\
\hline 167 & stylo & pen & 75 & 69 & 33 & 45 & & 52 & 49 \\
\hline 168 & crayon & pencil & 39 & 33 & 39 & 39 & & 32 & 36 \\
\hline 171 & piano & piano & 63 & 57 & 140 & 45 & & 52 & 61 \\
\hline 172 & cochon & pig & 34 & 33 & 33 & 23 & & 32 & 54 \\
\hline 173 & ananas & pineapple & 68 & 69 & 75 & 75 & & 40 & 54 \\
\hline 175 & pot à eau & pitcher & - & non & 51 & & & & 150 \\
\hline 176 & pince & pliers & + & non & 63 & 127 & & & 102 \\
\hline 177 & prise & plug & 92 & 114 & - & 69 & & & 136 \\
\hline 182 & lapin & rabbit & $34^{*}$ & 33 & 28 & 22 & & 32 & 36 \\
\hline 185 & réfrigérateur & refrigerator & 63 & - & 45 & & & & \\
\hline 187 & bague & ring & 75 & 75 & 45 & 51 & & & 87 \\
\hline 189 & patin à roulette & roller skate & 92 & non & 103 & & & & 136 \\
\hline 191 & $\operatorname{coq}$ & rooster & + & 75 & 39 & & 49 & & 102 \\
\hline 193 & voilier/bateau & sailboat & 34 & - & 75 & & 55 & & 30 \\
\hline 195 & sandwich & sandwich & 63 & 75 & 57 & 39 & & & 114 \\
\hline 196 & scie & saw & 68 & 75 & 57 & 69 & & 68 & 126 \\
\hline 197 & ciseaux & scissors & $34^{*}$ & 33 & 33 & 23 & 34 & 32 & 36 \\
\hline 198 & vis & screw & + & 93 & 69 & 81 & & & 102 \\
\hline 199 & tournevis & screwdriver & 92 & 69 & 51 & 69 & 67 & 79 & 82 \\
\hline 202 & mouton & sheep & 63 & 75 & 33 & 45 & & 52 & 61 \\
\hline 203 & chemise & shirt & 140.5 & 75 & 63 & 57 & & 91 & 136 \\
\hline 204 & chaussure & shoe & 34 & 33 & 23 & 22 & & & 36 \\
\hline 205 & jupe & skirt & + & 75 & 51 & 57 & & 32 & 82 \\
\hline 207 & luge & sled & 56 & 57 & 33 & & 61 & & 76 \\
\hline 208 & escargot & snail & 39 & 45 & 39 & 45 & & & 36 \\
\hline 211 & chaussette & sock & 34 & 33 & 23 & 23 & & 32 & 36 \\
\hline 215 & cuillère & spoon & $34^{*}$ & 33 & 23 & 22 & & & 30 \\
\hline 217 & étoile & star & 44 & 33 & 23 & 39 & & & 36 \\
\hline
\end{tabular}


APPENDIX (Continued)

\begin{tabular}{|c|c|c|c|c|c|c|c|c|c|}
\hline $\begin{array}{l}\text { Item } \\
\text { No. }\end{array}$ & French Name & English Name & $\begin{array}{c}\text { Present } \\
\text { Study }\end{array}$ & $\begin{array}{c}\text { Chalard } \\
\text { et al. } \\
(2003)\end{array}$ & $\begin{array}{l}\text { Pind } \\
\text { et al. } \\
(2000)\end{array}$ & $\begin{array}{c}\text { Morrison } \\
\text { et al. } \\
(1997)\end{array}$ & $\begin{array}{c}\text { Barbarotto } \\
\text { et al. } \\
(2005)\end{array}$ & $\begin{array}{c}\text { Pérez \& } \\
\text { Navalón } \\
(2005)\end{array}$ & $\begin{array}{c}\text { Álvarez \& } \\
\text { Cuetos } \\
(2007)\end{array}$ \\
\hline 218 & tabouret & stool & 68 & 69 & 75 & 51 & & & 173 \\
\hline 219 & cuisinière & stove & - & - & 45 & & & & 102 \\
\hline 220 & fraise & strawberry & 44 & 51 & 39 & 45 & 49 & 32 & 49 \\
\hline 222 & soleil & sun & 39 & 39 & 28 & 23 & & & 30 \\
\hline 224 & pull (over) & sweater & 68 & non & 23 & & & & 93 \\
\hline 225 & balançoire & swing & 75 & 75 & 57 & 51 & & & 43 \\
\hline 226 & table & table & 34 & 33 & 23 & 22 & 55 & 32 & 36 \\
\hline 227 & téléphone & telephone & $34^{*}$ & 33 & 23 & 23 & & & 36 \\
\hline 228 & télévision & television & 39 & - & 33 & 39 & & & 36 \\
\hline 232 & cravate & tie & 80 & 75 & 63 & 57 & & 68 & 61 \\
\hline 234 & grille-pain & toaster & 140.5 & non & 103 & 51 & & & 72 \\
\hline 235 & orteil & toe & - & - & - & & & & 36 \\
\hline 236 & tomate & tomato & 63 & 57 & 45 & 69 & 49 & 52 & 61 \\
\hline 237 & brosse à dent & toothbrush & 44 & non & 33 & & & & \\
\hline 239 & feu rouge & traffic light & 63 & 69 & 75 & & & & 49 \\
\hline 240 & train & train & 63 & 51 & 39 & 25 & & & 36 \\
\hline 241 & arbre & tree & 39 & 31 & 28 & 22 & & & 30 \\
\hline 162 & pantalon & trousers & $34^{*}$ & 33 & non & 25 & & 32 & \\
\hline 242 & camion & truck & $34^{*}$ & 33 & - & & & & 36 \\
\hline 243 & trompette & trumpet & 75 & 51 & 93 & 57 & 55 & 40 & 72 \\
\hline 244 & tortue & turtle & 39 & 33 & 33 & & & 32 & 36 \\
\hline 245 & parapluie & umbrella & 39 & 33 & 39 & 23 & & & 36 \\
\hline 250 & montre & watch & 39 & 45 & 51 & 39 & & & 36 \\
\hline 251 & arrosoir & watering can & 44 & 57 & - & & & & 49 \\
\hline 259 & clé & wrench & - & non & - & & & & 160 \\
\hline \multirow[t]{7}{*}{260} & zèbre & zebra & 56 & 51 & 51 & 45 & & 57 & 61 \\
\hline & & $M$ & 54.67 & 52.64 & 42.60 & 41.28 & 46.48 & 41.16 & 63.66 \\
\hline & & $S D$ & 23.69 & 21.10 & 19.71 & 20.77 & 10.45 & 13.61 & 39.32 \\
\hline & & Min & 34.00 & 30.56 & 22.50 & 22.10 & 34.00 & 32.00 & 30.00 \\
\hline & & Max & 140.50 & 140.50 & 140.00 & 126.50 & 66.50 & 91.00 & 185.00 \\
\hline & & Q1 & 34.00 & 33.00 & 32.50 & 23.40 & 34.00 & 32.00 & 36.00 \\
\hline & & Q3 & 68.00 & 68.50 & 50.50 & 50.50 & 54.50 & 45.00 & 76.00 \\
\hline
\end{tabular}

Note-A "-" denotes items for which the percentage of correct naming in adults was below 75\%. A "+" denotes outliers. The items acquired by children but not by adults according to the $75 \%$ rule are printed in boldface. *Items whose picture was named by at least $90 \%$ of children in the youngest age band.

(Manuscript received December 11, 2007; revision accepted for publication May 8, 2008.) 